\title{
The Influence of School Environment, Social Intelligence, and Self- Esteem toward Academic Achievement of Student in Rural Area
}

\author{
Miranti Rahmatika* \\ Department of Family and Consumer Sciences, \\ Faculty of Human Ecology, \\ Bogor Agricultural University \\ Neti Hernawati \\ Department of Family and Consumer Sciences, \\ Faculty of Human Ecology, \\ Bogor Agricultural University \\ *Corresponding author: miranti.rahmatika@yahoo.com
}

\begin{abstract}
Academic achievement of students is affected by several factors. This study aimed to analyze the effect of adolescent and family characteristics, school environment, social intelligence, and self-esteem toward academic achievement of rural adolescents. This study used the cross-sectional study design. The purposive method was used in selecting the research location. Data were collected from two senior high school students in Bogor District $(n=150)$ chosen by proportional random sampling. The result showed that gender and school environment had significantly positive effect on academic achievement. Conversely, family income had negative effect on academic achievement of rural adolescents.
\end{abstract}

Keywords: academic achievement, adolescent, self-esteem, school environment, social intelligence, rural area

\begin{abstract}
Abstrak. Pencapaian remaja untuk meraih prestasi akademik merupakan hasil dari interaksi antara berbagai faktor yang mempengaruhinya. Tujuan penelitian ini adalah untuk menganalisis pengaruh karakeristik remaja, karakteristik keluarga, lingkungan sekolah, kecerdasan sosial, dan self-esteem terhadap prestasi akademik remaja di wilayah perdesaan. Penelitian ini menggunakan desain cross-sectional study. Responden dalam penelitian ini berjumlah 150 siswa SMA di wilayah Kabupaten Bogor, Jawa Barat. Pemilihan lokasi penelitian ini dilakukan secara purposif dan penarikan contoh dilakukan dengan teknik proportional random sampling. Hasil uji regresi menunjukkan bahwa kecerdasan sosial dan self-esteem tidak memiliki pengaruh yang signifikan terhadap prestasi akademik. Jenis kelamin dan lingkungan sekolah ditemukan memiliki pengaruh positif signifikan terhadap prestasi akademik. Sebaliknya, pendapatan per kapita keluarga mempunyai pengaruh negatif signifikan terhadap prestasi akademik remaja perdesaan.
\end{abstract}

Kata kunci: kecerdasan sosial, lingkungan sekolah, perdesaan, prestasi akademik, remaja, selfesteem 


\section{Introduction}

One of the causes of the low quality of education in Indonesia is the gap of education quality between villages and towns, which has been a long-unresolved issue. According to Indonesian Statistics (2013), school enrollment rates in the age group of 16-18 years in urban areas tended to be higher $(69.18 \%)$ than those in rural areas $(58.23 \%)$. This suggests that the conditions of the urban population have greater opportunities for education than those living in rural areas. The gap is caused by the implementation of the education system in each area which is unevenly distributed.

Academic achievement in adolescents is one of the important aspects that need to be considered by a nation. Adolescents who have a desire to excel is the capital of a nation to produce qualified human resources. Adolescents' academic achievement is the result of interaction between the various factors that influence it. Those are factors that come from outside (external) and factors derived from inside (internal).

External factor which are suspected to affect the learning achievement of adolescents is the school environment. The whole school as a special social system with all of the factors that shape it can be a positive factor in the development of adolescents (Gunarsa and Gunarsa, 2004). Schools can spur students to improve their academic achievement or also can lower the academic achievement. It depends on the students' perception of the school environment. Results of the research conducted by Angus, Prater, and Busch (2009) has shown that students achieve higher grades in exams due to school healthy learning environment.

Achievement in adolescents is something grown, developed, and it is the result of learning through interaction with the environment (Gunarsa and Gunarsa, 2004). Adolescent interactions with the environment in schools occur repeatedly. It allows the teenager to face problems related to the atmosphere of the school, peers, group influence, and so forth. Unhealthy environments may cause deviant social behavior of adolescents, so that adolescents are required to adapt to their social environment. Their ability to adapt to the social environment is one of the elements to achieve social intelligence. The study of Shah and Sharma (2012) has indicated that there is a relationship between the student's ability to adapt to the school environment with social intelligence. Students who are concerned with the priority to meet the expectations of parents and the social expectation are the students who can adapt to the school environment as well. Social intelligence is an internal factor that affects the academic achievement of adolescents (Singh and Thukral, 2010). Their ability to interact and adapt to the social environment will make them confident and motivated to excel.

The establishment and maintenance of an effective social relationships is one of dimensions of adolescents' social intelligence. According to Parker (2006), confidence is essential in building a social relationship. Self-esteem is an internal factor in adolescents who could be expected to affect their academic achievement. Self-esteem in adolescents refers to the trust or sense of self or perceptions toward themselves. Students who have high self-esteem will perform various activities with high confidence based on the rational reasons. Conversely, students with low self-esteem would be difficult to adapt and tend to withdraw socially, and they can be easily influenced by others leading to difficulties for student achievement.

Several contemporary research on adolescent and learning activities tends to show various results. It is exciting for researchers to study more on the influence of the school environment, social intelligence and self-esteem of the academic achievement of 
high school students, especially in rural areas. Therefore, the purposes of this study were: (1) to identify the adolescent characteristics, family characteristics, school environment, social intelligence, self-esteem, and academic achievement of adolescent in rural areas; (2) to analyze the relationship between the school environment, social intelligence, self-esteem, and academic achievement of adolescent in rural areas; and (3) to analyze the influence of adolescent characteristics, family characteristics, school environment, social intelligence, and self-esteem on adolescents' academic achievement in rural areas.

\section{Method}

\section{Participants}

This study is part of a cross sectional study on the topic of "Factors Affecting the Achievement of Youth in Rural Areas". The location of this research was two public high schools chosen purposively. The selected schools were including the top 10 public schools with the highest number of students based on Bogor District Education Office in 2014. The proportional random sampling technique was implemented by selecting from $11^{\text {th }}$ grade students (science and social studies) on each school. As many as 150 students were elected to be samples of this study. After collecting the data, there were 132 qualified samples.

\section{Measures}

The collected data included primary and secondary data. Primary data were collected through self-report questionnaires filled out by the adolescent after receiving an explanation and guidance from researchers. School environment variables were measured by using modified instruments of nonphysical school environment developed by Utami (2014), which consisted of 64 items with the reliability value of 0.872 . Social intelligence was measured by using modified instrument of social intelligence used by Wulandari (2009), which consisted of 43 items with the reliability value of 0.835 . Students' self-esteem was measured by using modified Rosenberg Self-Esteem Scale (Rosenberg, 1965) and Social Texas Behavior Inventory-Form (Helmreich and Stapp, 1974) by Novariandhini (2011). There were 14 items with the reliability value of 0.867 . Secondary data covered academic achievement which was obtained from school containing the data of adolescents' grades.

\section{Analysis}

In categorizing the school environment variable, the index scores were used with the following cut-off: good (>80\%), fair $(60 \%-80 \%)$, and less $(<60 \%)$. The cut-off of social intelligence categorization is as follows: mature $(>80 \%)$, fairly mature $(60 \%$ $80 \%)$, and less mature $(<60 \%)$. Meanwhile, the category of self-esteem were divided into high $(>80 \%)$, medium $(60 \%-80 \%)$, and low $(<60 \%)$. Academic achievement of adolescents were divided into four categories: excellent (3.51-4.00), good (3.00-3.49), fair (2.50-2.99), and poor $(\leq 2.49)$ (Decree of Minister of Education and Culture No. 81A/2013). Descriptive analysis included the analysis on minimum value, maximum value, mean, standard deviation, and frequency. Inferential analysis used the Pearson 
correlation test (numerical data) to determine the relationship between the variables. While to look at the factors affecting self-esteem and academic achievement, the multiple linear regression analysis was used.

\section{Result}

\section{Sample and Family Characteristics}

Nearly all samples were in the category of late adolescence based on the age category by Papalia, Olds, and Fieldman (2008). The oldest sample was 18-year old adolescent and the youngest one was 15-year old adolescents with an average age of 16.71. By gender, the percentage of the greatest examples of female was 62.1 percent and male was 37.9 percent. About 56.8 percent of the total sample were science students and the rest were in the social studies (43.2\%).

The results showed that most of the age of fathers (78.8\%) and mothers (53.4\%) of sample was categorized into middle age (Santrock, 2007). Based on parent's length of education, the average length of education of father and mother was equivalent to junior high school in which father was 9.17 and mother was 8.44. Referring to the poverty line of West Java in 2014, there were as many as 62.9 percent of samples in this study that came from nonpoor families or were above the poverty line with an average income per capita per month of Rp548.206.

\section{School Environment}

School environment in this study referred to the samples' perception of the learning environment at school including learning processes, school interaction with parents, rules, and regulations that the sample encountered as a student in the process of learning. The result of descriptive analysis in Table 1 shows that more than half sample $(68.9 \%)$ perceive the school environment that was grouped into the fair category with the average value of the overall school environment index of 64.42. As many as 78 percents of the students perceived the dimensions of learning process in the fair category. Meanwhile, the dimensions of regulations and sanctions applied in school were perceived as poor by 53.8 percent of samples.

Table 1 Distribution of sample according to the category of school environment

\begin{tabular}{lcccccccc}
\hline Category & \multicolumn{2}{c}{ Learning process } & \multicolumn{2}{c}{$\begin{array}{c}\text { School interaction } \\
\text { with parents }\end{array}$} & $\begin{array}{c}\text { School regulation } \\
\text { and sanction }\end{array}$ & Total \\
\cline { 2 - 8 } & $\mathrm{n}$ & $\%$ & $\mathrm{n}$ & $\%$ & $\mathrm{n}$ & $\%$ & $\mathrm{n}$ & $\%$ \\
\hline Poor $(<60)$ & 20 & 15.2 & 66 & 50.0 & 71 & 53.8 & 38 & 28.8 \\
Fair $(60-80)$ & 103 & 78.0 & 62 & 47.0 & 61 & 46.2 & 91 & 68.9 \\
Good $(>80)$ & 9 & 6.8 & 4 & 3.0 & 0 & 0.0 & 3 & 2.3 \\
\hline Total & 132 & 100.0 & 132 & 100.0 & 132 & 100.0 & 132 & 100.0 \\
Min-Max & $39.8-91.9$ & $26.7-93.3$ & $38.5-79.5$ & $39.1-86.5$ \\
Mean \pm SD & $67.4 \pm 7.3$ & $58.1 \pm 12.6$ & $59.7 \pm 7.7$ & $64.4 \pm 7.3$ \\
\hline
\end{tabular}

\section{Social Intelligence}

Social intelligence is the ability to understand other people and how to react to different social situations (Goleman, 2007). Table 2 shows that the majority of sample $(79.5 \%)$ have a social intelligence in fairly mature category. Social intelligence in this 
study consisted of two dimensions, i.e., social awareness and social skill. Social awareness is the ability to feel the inner state of a person and to understand the feelings and thoughts. The results showed that more than half of the sample had a social awareness in fairly mature category, while the rest was spread evenly on mature and less mature categories. Dimension of social skill is an ability to rely on social awareness that allows a person to be able to interact effectively. The result showed that the social skill of more than half of the sample $(68.9 \%)$ was fairly mature.

Table 2 Distribution of sample according to the category of social intelligence

\begin{tabular}{lcccccc}
\hline Category & \multicolumn{2}{c}{ Social awareness } & \multicolumn{2}{c}{ Social skill } & \multicolumn{2}{c}{ Total } \\
\cline { 2 - 7 } & $\mathrm{n}$ & $\%$ & $\mathrm{n}$ & $\%$ & $\mathrm{n}$ & $\%$ \\
\hline Less mature $(<60)$ & 21 & 15.9 & 22 & 16.7 & 17 & 12.9 \\
Fairly mature (60-80) & 99 & 75.0 & 91 & 68.9 & 105 & 79.5 \\
Mature (>80) & 12 & 9.1 & 10 & 14.4 & 10 & 7.6 \\
\hline Total & 132 & 100.0 & 132 & 100.0 & 132 & 100.0 \\
Min-Max & $51.7-88.3$ & \multicolumn{2}{c}{$50.7-98.6$} & $52.7-93.8$ \\
Mean \pm SD & \multicolumn{2}{c}{$68.9 \pm 7.8$} & \multicolumn{2}{c}{$69.1 \pm 9.2$} & $69.0 \pm 7.6$ \\
\hline
\end{tabular}

\section{Self-Esteem}

Adolescence is a period when one starts to believe in the will, potential, and his ideals. A deep awareness of adolescent about himself make adolescent be able to perform self-assessment or evaluation of the self which is called as self-esteem (Santrock, 2003). In general, self-esteem refers to the overall evaluation of negative and positive against himself. Table 3 shows that more than half of the sample $(57.6 \%)$ had self-esteem in the medium category. A total of 35.6 percent of adolescent had low selfesteem. The rest was adolescent who had high self-esteem $(6.8 \%)$.

Table 3 Distribution of sample according to the category of self-esteem

\begin{tabular}{lcc}
\hline Self-Esteem & $\mathrm{n}$ & $\%$ \\
\hline Low $(<60)$ & 47 & 35.6 \\
Middle $(60-80)$ & 76 & 57.6 \\
High $(>80)$ & 9 & 6.8 \\
\hline Total & 132 & 100.0 \\
Min-Max & & $35.7-90.4$ \\
Mean \pm SD & \multicolumn{2}{c}{} \\
\hline
\end{tabular}

\section{Academic Achievement}

Academic achievement is the result achieved by individual assessment after experiencing a learning process within a certain period. Assessment of learning outcomes aimed to determine students' learning outcomes formulated in the form of numbers (Suryabrata, 2006). Table 4 shows that the largest percentages of the sample (92.4\%) have good academic achievement while the rest have fair academic achievement (7.6\%). There were no samples in this study who achieved poor and excellent categories of academic achievement. The data are presented in Table 4.

Table 4 Distribution of sample according to the category of academic achievement

\begin{tabular}{lcc}
\hline Academic achievement & $\mathrm{n}$ & $\%$ \\
\hline Poor $(\leq 2.49)$ & 0 & 0.0 \\
Fair $(2.50-2.99)$ & 10 & 7.6 \\
Good $(3.00-3.49)$ & 122 & 92.4
\end{tabular}




\begin{tabular}{|c|c|c|}
\hline Excellent (3.50-4.00) & 0 & 0.0 \\
\hline Total & 132 & 100.0 \\
\hline Min-Max & & $2.8-3.5$ \\
\hline Mean \pm SD & & $3.20 \pm 0.2$ \\
\hline
\end{tabular}

\section{The Correlation between the School Environment, Social Intelligence, Self-Esteem and Academic Achievement}

The results of correlation analysis showed that the school environment was correlated with the social intelligence $(r=0.221 ; \mathrm{p}<0.05)$ and with self-esteem $(r=$ $0.292 ; \mathrm{p}<0.01)$. It indicates that the better the school environment, the higher the social intelligence and self-esteem of adolescent. Social intelligence and self-esteem had a significantly positive correlation between them $(r=0.543 ; \mathrm{p}<0.01)$. It implies that the better the ability of adolescent adapting with the social environment, the higher their self-esteem will be. There was a significantly positive correlation between academic achievement and school environment $(\mathrm{r}=0.213$; $\mathrm{p}<0.05)$, as well as between academic achievement and self-esteem $(r=0.256 ; \mathrm{p}<0.01)$. Thus, the better the school environment and the higher self-esteem owned by adolescent, the higher the academic achievement will be. Meanwhile, correlation between social intelligence and academic achievement could not be identified in this research.

\section{The Influence of Sample Characteristics, Family characteristics, the School Environment, Social Intelligence and Self-Esteem on Academic Achievement}

Regression analysis (Table 5) showed that the adjusted coefficient of determination (Adjusted R Square) was approximately 0.182, indicating that as many as 18.2 percent of academic achievement was influenced by variables analyzed in this study while as many as 81.8 percent was explained by other variables that were not analyzed. Factors affecting academic achievement in this study were gender, family income, and school environment.

Table 5 The influence of sample characteristics, family characteristics, school environment, social intelligence, and self-esteem on academic achievement

\begin{tabular}{lccc}
\hline Variable & \multicolumn{3}{c}{ Academic achievement } \\
\cline { 2 - 4 } & $\begin{array}{c}\text { Unstandardized } \\
\text { coefficient }(\mathrm{B})\end{array}$ & $\begin{array}{c}\text { Standardized } \\
\text { coefficient }(\beta)\end{array}$ & Sig. \\
\hline Constant & 2.839 & - & 0.000 \\
Gender $(0=$ male; $1=$ female) & 0.085 & 0.276 & $0.001^{* * *}$ \\
Length of education of mother & 0.002 & 0.042 & 0.645 \\
Family size & 0.007 & 0.082 & 0.392 \\
Family income & $-7.331 \mathrm{E}-8$ & -0.250 & $0.013^{* *}$ \\
School environment & 0.003 & 0.154 & $0.067^{*}$ \\
Social intelligence & 0.001 & 0.027 & 0.778 \\
Self-esteem & 0.002 & 0.153 & 0.121 \\
\hline $\mathrm{F}$ & \multicolumn{3}{c}{5.167} \\
Sig & \multicolumn{3}{c}{0.000} \\
$\mathrm{R}^{2}$ & 0.226 \\
$\mathrm{R}^{2}$ Adjusted & 0.182 \\
\hline Note. $(*)$ significant at $\mathrm{p}<0.1 ;(* *)$ significant at $\mathrm{p}<0.05 ;(* * *)$ significant at $\mathrm{p}<0.01$ \\
\end{tabular}

Gender $(B=0.085)$ had a significantly positive effect on academic achievement. That is, the girls would tend to raise the academic achievement of 0.276 points. Family income had a negative effect on academic achievement $(\beta=-7.331 \mathrm{E}-8)$, indicating that 
the increasing of one rupiah will lower academic achievement. In contrast, the school environment had a positive influence on academic achievement $(\beta=0.154)$. It implies that any increase in one point of the school environment quality will raise academic achievement by 0.154 points.

\section{Discussion}

Previous studies have found that gender differences affect learning achievement (Jacobs et al., 2002; Linver, Davis-Kean, and Eccles, 2002; Salami, 2013). These results indicated that gender affects academic achievement in which girls tend to raise their academic achievement that is higher than boys did. This is in line with the results of Joshi and Srivastava's study (2009) who find that the academic achievement of women tend to be higher than that of men. According to Sonja et al. (2009), girls are more cooperative with school regulations and show more competency in performance and academic tasks.

Atmosphere of school environment perceived by adolescents is the result of interaction between adolescents with all the supporting factors of learning in school. Students who feel comfortable with the school environment will have a positive perception toward the school so that they will be able to understand the subject and the academic achievement that are even better to be reached. The results of this study showed that non-physical school environment influenced adolescents' academic achievement in rural areas. This is in line with the result of Wang and Holcombe's study (2012) revealing that a positive perception of the school environment can influence adolescents behavior, affection, and cognition, which then affects their academic achievement. This is also consistent with the results that students with high academic grades on exams are students who come from a healthy school environment (Angus, Prater, and Busch, 2009).

Based on the model of Bronfenbrenner environmental development, the school that belongs to the micro system can affect the development of the individual (Cobb, 2001). School is the closest system that directly interacts with adolescents so that it can affect their social behavior. According to Asrori (2004), through the school environment, students learn to build relationships with school friends who come from diverse families with different social background. The result showed that the school environment had a significantly positive relationship with adolescents' social intelligence. This is in accordance with the result of Shah and Sharma's study (2012) which has found that there is a significant relationship between social intelligence with the adjustment to the school environment. This indicates that the quality of the school environment may help adolescent in rural areas to optimize their social intelligence.

A person's ability to cooperate and communicate with the social environment can help one in achieving their academic achievement. Some previous research have shown that social intelligence is positively associated with adolescents' academic achievement (Puar and Thukar, 2012; Bordhan, 2015). In contrast, this research showed that social intelligence did not have a significant relationship with achievement. However, this finding is in line with Wulandari's study (2009) and Nurhayati's study (2011) who find that social intelligence do not have a significant relationship with achievement. The regression analysis also showed that the influence of social 
intelligence did not have a significant effect on the academic achievement of adolescent in rural areas. According to Franky and Chamundeswari (2014), the success of students in their academic achievement is not dependent on how the person adjusts to the environment, but rather how the person understand to develop and fully use his ability.

According to Parker (2006), the important thing owned by someone in fostering a social relationship is self-esteem. Tafarodi and Milne (2002) suggest two dimensional constructs of Rosenberg's self-esteem, namely self-liking and self-competence. Selfesteem is not only a self-assessment, but also a part of consequence as the results of comparing oneself with another person. The results showed that social intelligence was positively associated with self-esteem. People begin to realize that he is valuable when interacting with their social environment. Adolescents with high self-esteem are also active. Moreover, they can express themselves well, succeed academically and in organizing social relations. In addition, a healthy self-esteem can be formed and nurtured by several contributing factors, one of them is through coaching in schools. This research also found that school environment had a significantly positive correlation with self-esteem. Coaching in school is to produce an independent, proactive, and noble person, and to develop students' confidence (Rohayati, 2014). Shy students can not participate actively in learning process, so that the student is not able to resolve the existing problems in school, both academically and socially (Miraei, 2005).

The result of the relationship between self-esteem with academic achievement showed a significantly positive correlation between the variables. This is consistent with the result of Irawati and Hajat's study (2012) indicating that there is a significantly positive relationship between self-esteem and academic achievement. However, the regression test results showed that there was no significant effect of self-esteem on academic achievement. It is suspected that rural adolescents who have different selfesteem levels are in the same category of academic achievement. The result also indicates that adolescents who have a good record do not always have a high level of self-esteem, and vice versa (Alfiasari, Latifah, and Wulandari, 2011).

Slameto (2010) argues that the family economic condition is tightly associated with children's learning. Students need not only their basic needs to be fulfilled but also facilities that support their learning process. The learning facilitation may only be fulfilled if the family has a good financial background. It is strengthen by Nurasiyah's study (2011) which has revealed through her research that parental income had a positive effect on children's academic achievement. However, this study showed different result that family income had a negative effect on academic achievement. Therefore, the higher the family income, the lower the academic achievement will be. This finding indicates that in meeting the family needs, parents are so busy for a living, that they do not pay much attention towards their children's education. This is consistent with the opinion of Santrock (2003) which states that the attainment of parents (rich/successful) does not necessarily motivate adolescent to learn and achieve success. 


\section{Conclusion and Recommendation}

\section{Conclusion}

The results showed that most adolescents in this study perceive the school environment in fair category. The highest proportion of adolescents' social intelligence is in fairly mature category. Adolescents' self-esteem in this study is still not optimal, which is in medium category. Based on the data distribution, adolescents' academic achievement is in the category of good and fair. Multiple linear regression analysis showed that the increasing of one rupiah in family income per capita will decrease adolescents' academic achievement. The adolescents' positive perception on the nonphysical school environment affects their academic achievement. In addition, gender also affects adolescents' academic performance, in which girls tend to get higher academic achievement than boys. Social intelligence and self-esteem have no significant effect on adolescents' academic achievement. This study has several limitations, such as the research location and number of sample. Carrying out in only one rural area at Bogor with a small number of sample makes the results cannot be generalized to represent the rural area as a whole.

\section{Recomendation}

Based on the results of this study, it was found that the school environment could be a motivating factor for improving adolescents' academic achievement in rural areas. Therefore, schools should be able to create the learning process that is able to help in increasing the students' potential. Other findings stated that girls were more likely to have higher academic achievement. Thus, teachers and parents are more expected to motivate and supervise boy students in order to improve their academic achievement that is important to be taken into account. Parents earning a living to meet the needs of families are usually busy. This makes them reduce their attention on children's academic. Meanwhile, this study proved that family income per capita had negative effect on adolescents' academic achievement. The fact that parents are also expected to improve their supervision and guidance to the education of their children is also important to be taken into account. For further research, it is recommended to investigate the factors that influence adolescents' academic achievement from the factors of family environment such as parenting styles and school environment together with the various background of samples. It is also expected to carry out the reearch in wider area and involve bigger number of samples so that the results may be able to represent and generalize other similar locations.

\section{Reference}

Alfiasari, Latifah, M., \& Wulandari, A. (2011). Pengasuhan otoriter berpotensi menurunkan kecerdasan sosial, self-esteem, dan prestasi akademik remaja [Authoritarian parenting potentially lower social intelligence, self-esteem and academic achievement of adolescents]. Jurnal Ilmu Keluarga dan Konsumen, 4(1), 46-56. 
Angus, J. M., Prater, D. L., \& Busch, S. (2009). The effects of school culture and climate on student achievement. International Journal Leadership In Educaton, 12(1), 73-84. doi : 10.1080/13603120701576241.

Asrori, M. (2004). Psikologi Remaja: Perkembangan Perserta Pendidik [Adolescent Psychology: Development Educator Participants]. Jakarta, Indonesia: Bumi Aksara.

Bordhan, S. (2015). Role of social maturity in academic achievement of high school students. International Journal of Applied Research, 1(7), 44-46. Retrieved from http://www.allresearchjournal.com/archives/?year=2015\&vol=1\&issue=7\&part=A\& articleId=266.

Cobb, N. J. (2001). Adolescence: Continuity, Change, and Diversity (4th ed.). California, CL: Mayfield Publishing Company.

Franky, D., \& Chamundeswari, S. (2014). Psycho-social correlates of academic achievement of students. International Journal of Current Research and Academic Review, 2(2), 148-158. Retrieved from http://www.ijcrar.com/vol-22/Deepa\%20Franky\%20and\%20S.Chamundeswari.pdf.

Goleman, D. (2007). Social Intelegence. Jakarta, Indonesia: PT. Gramedia Pustaka Utama.

Gunarsa, S. D., \& Gunarsa, Y. S. D. (2004). Psikologi Praktis: Anak, Remaja dan Keluarga [Practical Psychology: Children, Youth and Families] (7th ed.). Jakarta, Indonesia: Gunung Mulia.

Helmreich, R., \& Stapp, J. (1974). Short forms of the Texas Social Behavior Inventory (TSBI), an objective measure of self-esteem. Bulletin of the Psychonomic Society, 4(5), 473-475. doi:10.3758/BF03334260.

Irawati, N., \& Hajat, N. (2012). Hubungan antara harga diri (self-esteem) dengan prestasi belajar pada siswa SMKN 48 di Jakarta Timur [The relationship between self-esteem and academic achievement in students 48 Vocational School in East Jakarta]. Jurnal Ecosains, $X(2)$, 193-210. Retrieved from http://www.econosains.com/attachments/article/28/NURAHMA.pdf.

Jacobs, J. E., Lanza, S., Osgood, D. W., Eccles, J. S., \& Wigfield, A. (2002). Changes in children's self-competence and values: Gender and domain differences across grades one through twelve. Child Development, 73(2), 509-527. Retrieved from http://www.rcgd.isr.umich.edu/garp/articles/eccles02h.pdf.

Joshi, S., \& Srivastava, R. (2009). Self-esteem and academic achievment of adolescents. Journal of the Indian Academy of Applied Psychology, 35, 33-39. Retrieved from http://medind.nic.in/jak/t09/s1/jakt09s1p33.pdf.

Linver, M. R., Davis-Kean, P., \& Eccles, J. E. (2002). Influences of Gender on Academic Achievement. Presented at the biennial meetings of the Society for Research on Adolescence, New Orleans, LA.

Miraei, R. (2005). The relationship between Self esteem, Self Concept and Academic Achievement among Junior of High School Students (Master's thesis). Tarbiat Moallem University, Iran.

Novariandhini, D. A. (2011). Self-Esteem, self-efficacy, motivasi belajar dan prestasi akademik siswa SMA pada berbagai model pembelajaran [Self-esteem, selfefficacy, learning motivation and academic achievement of high school students at various learning models] (Undergraduate thesis). Retrieved from http://repository.ipb.ac.id/handle/123456789/52924.

Nurasiyah. (2011). Pengaruh tingkat pendapatan dan pendidikan orang tua tehadap prestasi belajar ekonomi siswa kelas XI IPS di SMA Nurul Falah Pekanbaru [Effect 
of income and education level of the parents to the student achievement economics class XI IPS in Nurul Falah High School Pekanbaru] (Undergraduate thesis). Retrieved from http://digilib.uir.ac.id/dmdocuments/pea,nur\%20aisyah.pdf.

Nurhayati, S. (2011). Analisis kecerdasan emosional, kecerdasan sosial, self-esteem, dan prestasi akademik pada mahasiswa penerima Program Beasiswa Santri Berprestasi (PBSB) IPB [Analysis of emotional intelligence, social intelligence, self-esteem and academic achievement in students receiving Pupils Achievement Scholarship Program (PBSB) IPB] (Undergraduate thesis). Retrieved from http://repository.ipb.ac.id/handle/123456789/47468.

Papalia, D. E., Olds, S. W., \& Feldman, R. D. (2008). Human Development (10th ed.). New York, NY: The McGraw Hill Companies, Inc.

Parker, D. K. (2006). Menumbuhkan Kemandirian dan Harga Diri Anak [Fostering Independence and Self-Esteem Children]. Jakarta, Indonesia: Anak Prestasi Pustaka.

Puar, S. S., \& Thukral, P. (2012). Role of social maturity in academic achievement of high school students. International Journal of Educational and Psychological Research, 1(1), 6-11. Retrieved from http://www.academia.edu/3317329/Social_maturity_and_academic_achievement_of _high_school_students.

Rohayati, I. (2014.) Usaha sekolah untuk mengembangkan ras percaya diri siswa di SD Muhammadiyah Karangbendo Banguntapan Bantul [School efforts to develop self-confidence of students in Muhammadiyah Elementary School Karangbendo Banguntapan] (Undergraduate thesis). Retrieved from http://digilib.uinsuka.ac.id/14274/.

Rosenberg, M. (1965). Society and The Adolescent Self-Image. Princeton, NJ: Princeton University Press.

Salami, C. G. W. (2013). Gender and academic achievement in Delta State University Asaba. Journal of Education and General Studies, 2(3), 118-126. Retrieved from http://universalresearchjournals.org/ujegs/pdf/2013/March/Salami.pdf.

Santrock, J. W. (2003). Perkembangan Remaja [Adolescent Development] (6th ed.). (Adelar S, Saragih S, Trans.; Kristiadji, Sumiharti Y, Eds.). Jakarta, Indonesia: Erlangga.

Santrock, J. W. (2007). Perkembangan Anak [Child Development] (Rachmawati M, Kuswanti, Anna, Trans.; Hardani W, Ed.). Jakarta, Indonesia: Erlangga.

Shah, J. K., \& Sharma, B. (2012). A study on Social Maturity, School Adjustment and Academic achievement among residential school girls. Journal of Education and Practice, 3(7), 69-80. Retrvied http://iiste.org/Journals/index.php/JEP/article/view/1852/1807.

Singh, S., \& Thukral, P. (2010). Social Maturity and Academic Achievement of High School Students. Canadian Journal on Scientific and Industrial Research, 1(16).

Slameto. (2010). Belajar dan Faktor-Faktor yang Mempengaruhinya [Learning and Factors That Affect It]. Jakarta, Indonesia: PT. Rineka Cipta.

Sonja, P., Milena, V. Z., Jana, K., \& Cirila, P. (2009). Students' social behaviour in relation to their academic achievement in primary and secondary school: Teacher's perspective. Psihologijske Teme, 18(1), 55-74.

Statistics Indonesia. (2013). Angka partisipasi sekolah (APS) penduduk usia 7-18 tahun menurut tipe daerah, jenis kelamin dan kelompok umur, 2009-2013 [School enrollment rates of the population aged 7-18 according to the type of region, gender 
and age groups, 2009, 2013]. Retrieved from https://www.bps.go.id/linkTabelStatis/view/id/1613.

Suryabrata, S. (2006). Psikologi Pendidikan [Educational Psychology]. Jakarta, Indonesia: PT. Raja Grafindo Persada.

Tafarodi, R. W., \& Milne, A. B. (2002). Decomposing global self-esteem. Journal of Personality Assessment, 70(4), 443-484.

Utami, A. N. (2014). Pengaruh gaya pengasuhan dan lingkungan nonfisik sekolah terhadap karakter remaja [The influence of parenting style and non-physical environment of schools on teenage characters] (Undergraduate thesis). Retrieved from http://repository.ipb.ac.id/handle/123456789/72054.

Wang, M. T., \& Holcombe, R. (2010). Adolescent's perception of school environment, engagement, and academic achievment in Middle School. American Educational Research Journal. 47(3), 633-662. doi: 10.3102/0002831209361209.

Wulandari, A. (2009). Analisis persepsi gaya pengasuhan orang tua, keterampilan sosial, prestasi akademik, dan self-esteem mahasiswa Tingkat Persiapan Bersama $(T P B)$ di Institut Pertanian Bogor [Analysis of the perception of the style of parenting, social skills, academic achievement and self-esteem of students Preparation Level Joint (TPB) at Bogor Agricultural University] (Unpublished undergraduate thesis). Bogor Agricultural University, Bogor, Indonesia. 